\section{Interrelationship Among Seed Quality Parameters and Fungi Associated with Seeds of Cotton (Gossypium} Hirsutum L.) Amina Khatun', Shamim Shamsi ${ }^{*}$ and Ma Bashar ${ }^{2}$

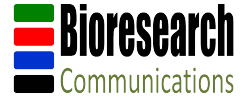

Bioresearch Communications

Volume 8, Issue 1, January 2022

DOI:

https://doi.org/10.3329/brc.v8i1.57045

Department of Botany, University of Dhaka, Dhaka-1000, Bangladesh

\begin{abstract}
A total of twenty nine species of fungi namely Aspergillus aculeatus Lizuka, $A$. flavus Link, $A$. fumigatus Fresenius, $A$. niger Van Tiegh, A. nidulans Eidam, A. subramanianii Visagie, Frisvad \& Samson, A. tamariikita G., A. toxicarius Murak, A. wentii Wehmer, Curvularial unata (Wakker) Boedijn, Colletotrichum gloeosporioides (Penz.) Sacc., C. gossypii Southw., Chaetomium globosum Kunze., Fusarium moniliforme J. Shelden, F. nivale (Fr.) Sorauer, F. oxysporum Schlechtendal, F. fujikuroi Nirenberg, F. solani(Mart.) Sacc., Lasiodiplodiatheobromae (Pat.) Griffon \& Maubl., Meyerozyma guilliermondii (Wick.) Kurtzman \& M. Suzuki., Mucor sp. P. Micheli ex L., Penicillium aculeatum Raper\& Fennell, Penicillium citrinum Thom, Rhizoctonia solani Khun., Rhizopus stolonifer (Ehrenb.) Vuill., Rhizopus oryzae Went \& Prins. Geerl., Rhizo mucor sp. Luce t \& Costantin, Syncephalastrum racemosum Cohn and Trichoderma viride Pers. were found to be associated with the seeds of 14 varieties viz. CB-1 to CB-14 of cotton. Seed quality analysis showed that percentage of pure seeds, germination, moisture, seedling mortality and associated fungi with different varieties of cotton seeds varies from $97.08-99.92 \%, 80-93 \%, 10-11.3 \%, 16.05-50.30 \%$ and $24-78.0 \%$ respectively. Present study deals with estimation of interrelationship between some quality factors through correlation and regression analysis are important for the assessment of seed quality. There were negative correlations between seedling mortality and purity percentage and between germination rate and fungus frequency. On the other hand, positive correlations were found between germination rate and purity percentage, between seedling mortality and fungus frequency, between purity percentage and fungus frequency, between germination rate and seed moisture and between fungus frequency and seed moisture. CB 8 was superior from the other cotton variety as it showed higher physical purity of seed (98.41\%), higher seed germination (92\%), lower fungal incidence (24\%) and lower mortality of seedling $(23.91 \%)$.
\end{abstract}

KEYWORDS: Associated fungi, Cotton seeds, Correlation and regression analysis, Germination, Mortality, Purity, Quality analysis, Seed moisture

RECEIVED: 12August 2021, ACCEPTED: 300ctober 2021

TYPE: Original Research
CORRESPONDING AUTHOR:Dr. Shamim Shamsi, Department of Botany, University of Dhaka, Dhaka-1000, Bangladesh.

Email: prof.shamsi@gmail.com

\section{Introduction}

The cotton plant belongs to the family Malvaceae. It is a shrub native to tropical and sub-tropical regions around the world. It is the major textile fiber used by man in the world and playing a key role in economic and social welfare ${ }^{1}$. It is grown primarily as a fiber crop and protein rich animal food ${ }^{2}$. It provides livelihood to about sixty million people and is an important agricultural commodity providing remunerative income to millions of farmers both in developed and developing countries.

Cotton is cultivated more than 80 countries of the world, which represents $2.5 \%$ of the cultivated land. In Bangladesh 14 upland cotton varieties (CB-1 to CB-14) and 3 hill cottons (HC-1, HC-2 and HC-3) have been released ${ }^{3}$.

Seed-borne fungi affect the quality of seeds at all stages of production, from the cropping stages until post-harvest, processing, storage and marketing ${ }^{4}$. Fungi are the largest group of the seed-borne pathogens. A large number of pathogenic fungi transmitted through seeds. The associated fungi with cotton seeds are particularly important because they reduce seed germination, affect seedling and flowering stage and also reduce the grain quality. Cotton production is being reduced due to the presence of some harmful pathogens. So far 20 types of symptoms and 52 species of fungi have been reported on cotton plant from various cotton growing areas of the world. In Bangladesh, a total of 14 diseases of cotton were recorded $^{5}$. Among these, 12 diseases are caused by fungal pathogens. Alternaria tenuis, Aspergillus flavus, A. niger, A. fumigatus, Fusarium moniliforme and Rhizopus nigricans are predominant in Bangladesh ${ }^{6}$.

The farmers in our country are not aware about the seed germination percentage, seed moisture, seed purity and seedling mortality and associated fungal pathogens. As a result, the quality of the freshly harvested seeds at farm level is very unsatisfactory, resulting crop failure and reduction of yield. If seed quality is maintained by testing before sowing, then possible disease could be controlled during seedling and flowering stages. So, it is expected that yield improvement could be achieved at higher rate by controlling the quality of seeds in Bangladesh. 
Correlation co-efficient that helps to know the degree of relationship between two variables and regression is the study of simultaneous variation between two or more variables. Correlation is a measure of the relationship between two or more variables. Correlation coefficients can range from -1.00 to +1.00 . The value of -1.00 represents a perfect negative correlation while a value of +1.00 represents a perfect positive correlation. A value of 0.00 represents a lack of correlation. Results of analysis of the interrelationships among quality factors i.e., storage mycoflora, seed germination, purity, moisture and seedling mortality gave valuable information about which steps of agro techniques of cotton growing needs more attention to enhance best quality and quantity of yield.

However, this work relates the seed health condition of cotton and estimate interrelationship among some quality factors through correlation and regression analysis.

\section{Materials and Methods \\ Collection of samples}

Seed samples of CB-1 to CB-14 were collected from Cotton Research, Training and Seed multiplication Farm, Sreepur, Gazipur after harvesting. Then they are kept in clean glass jars, labeled properly and preserved at room temperature for subsequent use. The experiment was conducted in the Mycology and Plant Pathology Laboratory, Department of Botany, University of Dhaka.

\section{Isolation and identification of fungi}

The fungi were isolated from the collected seed samples following the "Tissue Planting method" on PDA medium", "Blotter method" and "Paper Towel method", Morphological identification of the isolates was determined following the standard literatures $^{9-17}$. And the molecular identification of the isolated fungi was done following the method of Amer et al. ${ }^{18}$ with some modifications.

Per cent frequency of the occurrence of the fungal isolates was calculated by adopting the formula of Spurr and Wetly ${ }^{19}$.

Calculation of purity, germination, seedling mortality and moisture content

To calculate the physical purity of seeds, 100 gm seeds per sample were examined. To analysis the seed quality, the ratio of pure seeds, seed of other species, inert matter, and weed seeds of different samples were separated and recorded. Purity percentages of seeds were determined according to the method described by Khatun and Shamsi ${ }^{20}$.

For determination of germination, 300 seeds of each sample were taken and placed in 30 PDA plates. Plates were then incubated at room temperature for 7 days. Seeds producing both plumule and radical were considered as germinated seeds. Germination was recorded after 7 days and expressed as percentage.

Seedling mortality was determined after 10 days of incubation. Mortality percentages of seeds were determined according to the method described by Shamsi and Khatun ${ }^{21}$.

Moisture content of the seeds of different varieties of cotton was measured by using moisture meter (Model: GMK 303RS, Korea).

\section{Estimation of Interrelationships}

Interrelationships among seed mycoflora, seed germination, purity, seedling mortality and seed moisture of different varieties of cotton seeds were measured through correlation and regression analysis ${ }^{22}$. Correlation is a measure of the relationship between two or more variables. Correlation coefficients can range from -1.00 to +1.00 . The value of -1.00 represents a negative correlation while a value of +1.00 represent a positive correlation.

Analysis of data

Data were evaluated by analysis of variance (ANOVA) by using STAR statistical program and means were compared using Duncan's Multiple Range Test (DMRT).

\section{Results and Discussion}

Fungi isolated from different varieties of cotton seeds

Twenty nine species of fungi viz. Aspergillus aculeatus Lizuka, A. flavus Link, A. fumigatus Fresenius, A. niger Van Tiegh, A. nidulans Eidam, A. subramanianii Visagie, Frisvad \& Samson, A. tamariiKita G., A. toxicarius Murak, A. wentii Wehmer, Curvularia lunata (Wakker) Boedijn, Colletotrichum gloeosporioides (Penz.) Sacc., C. gossypii Southw., Chaetomium globosum Kunze., Fusarium moniliforme J. Shelden, F. nivale (Fr.) Sorauer, F. oxysporum Schlechtendal, F. fujikuro iNirenberg, F. solani (Mart.) Sacc., Lasiodiplodia theobromae (Pat.) Griffon \& Maubl., Meyerozyma guilliermondii (Wick.) Kurtzman \& M. Suzuki., Mucor sp. P. Micheli ex L., Penicillium aculeatum Raper\& Fennell, Penicillium citrinum Thom, Rhizoctonia solan $i$ Khun., Rhizopus stolonifer (Ehrenb.) Vuill., Rhizopus oryzae Went \& Prins. Geerl., Rhizomucor sp. Lucet \& Costantin, Syncephalastrumr acemosum Cohn and Trichoderma viride Pers. were isolated from the seeds of 14 varieties (CB 1- CB 14) of cotton.(Fig.1). 

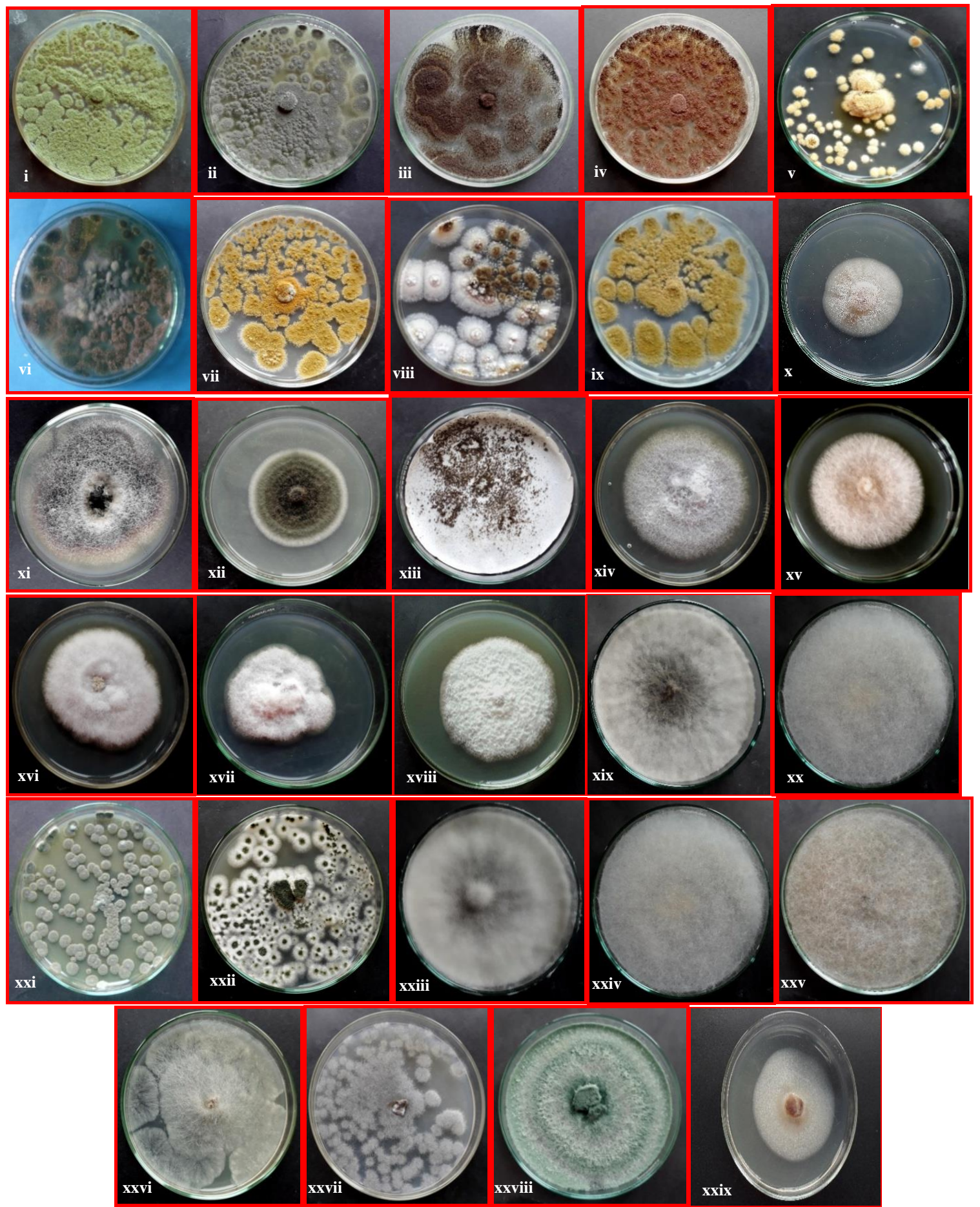

Figure 1.Fungi associated with seeds of different varieties of cotton (CB 1-14) i: Aspergillus flavus; ii: A. fumigatus; iiiF: A. niger; iv: A. aculeatus; v: A. subramanianii; vi: Aspergillus tamarii; vii: A. wentii; viii: A. toxicarius;ix: A. nidulans; x: Colletotrichum gloeosporioides; xi: C. gossypii; xii:Curvularia lunata;xiii: Chaetomium globosum; xiv: Fusarium oxysporum; xv: F. nivale; xvi: F. moniliforme; xvii: F. fujikuroi; xviii: F. solani.xix: Lasiodiplodia theobromae; xx: Mucor sp.; xxi: Penicillium citrinum; xxii: Penicillium aculeatum; xxiii: Rhizoctonia solani; xxiv: Rhizopus oryzae; xxv: Rhizopus stolonifer; xxvi:Rhizomucor sp.;xxvii:Syncephalastrumracemosum; xxviii: Trichoderma viride; xxix:Meyerozyma guilliermondii.

\section{Quality analysis of different cotton varieties}

Quality status of 14 varieties of cotton seeds were determined by seed quality analysis in table 1. Quality analysis showed that percentage of pure seeds were ranged from $97.08-99.92 \%$. The highest purity percentage was found in CB 13 (99.92) and lowest (97.08) was found in CB12. CB 10 showed maximum seed germination (93\%) while CB 4 showed minimum seed germination $(80 \%)$. The highest mortality percentage was observed in CB $11(50.30 \%)$ while lowest was observed in CB $7(16.05 \%)$. The highest percentage of associated fungi was found in CB 10 (78\%) and lowest in CB 8 (24\%). Maximum percentage of seed moisture was noticed in CB12 (11.3\%) and minimum in CB5 (10\%) (Table 1). 


\section{Interrelationships between the quality factors}

In this study, some interrelationship between the quality factors through correlation and regression analysis has been estimated which is very much important in controlling seed quality. Significant relationship has been estimated in all the cases (Fig. 2A-D and Fig. 3A-C).
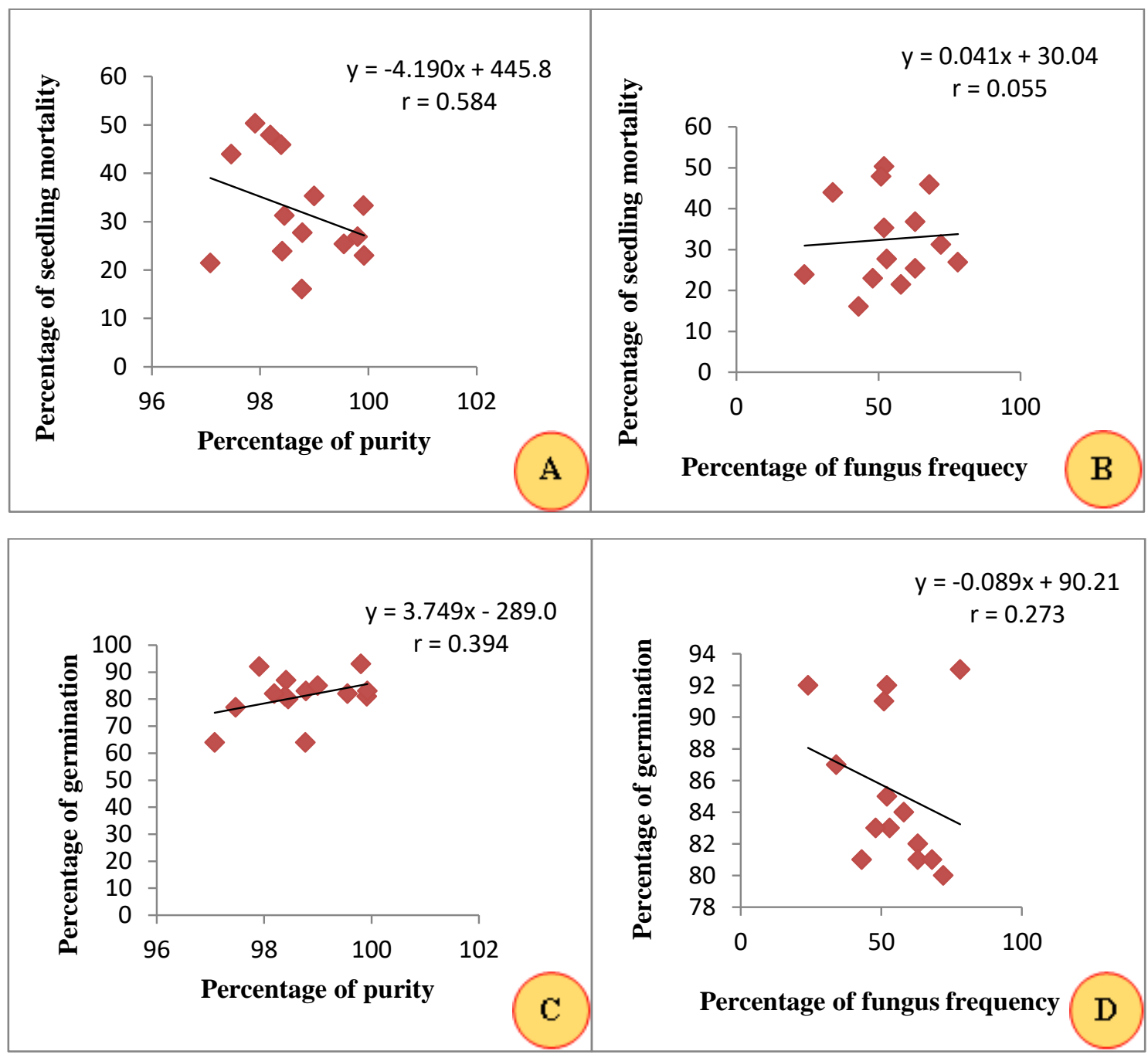

Figure 2.Correlation co-efficient and regression equation between A. percentage of seedling mortality and percentage of purity B. percentage of seedling mortality and percentage of fungus frequency C. percentage of germination and percentage of purity $\mathrm{D}$. Percentage of germination and percentage of fungus frequency.

Fig. 2A shows the relationship between seedling mortality and purity percentage and it shows negative correlation between two variables. It is evident that the regression line gives a downward slopping curve, which means that the increase of one variable decrease of other variable i.e., when purity percentage of seeds increases then percentage of seedling mortality decreases and vice versa. The correlation coefficient value between seedling mortality and physical purity of seeds was -0.584 (Table 2).

The relationship between seedling mortality and occurrence of fungi shows positive correlation between two variables (Fig. 2B). Here regression line gives an upward slopping curve, which indicates that both the variable change in the same direction i.e., increase or decrease of one variable increase or decrease of another variable. The mortality of seedling increases when the percentage of fungi increased and vice versa. The correlation co-efficient value between percentage of fungi and seedling mortality was +0.055 (Table 2).
The relationship between germination rate and purity percentage shows positive correlation between two variables (Fig. 2C).

Here regression line gives an upward slopping curve, which means that both the variable changes in the same direction. The correlation co-efficient value between germination rate and physical purity was +0.394 (Table 2 ).

Fig. 2D shows the relationship between germination rate and frequency percentage of fungi. It shows negative correlation between two variables. Here the regression line gives a downward slopping curve which means that germination of seeds increases when the percentage of fungi increases or the germination of seed increases when the percentage of fungi decreases. In the present study, the correlation co-efficient value between percentage of fungi and percentage of germination was -0.273 (Table 2).

The relationship between fungus frequency and purity percentage shows positive correlation between two variables (Fig. 3A). Here regression line gives upward slopping curve, 
which means that increase or decrease of one variable increase or decrease of another variable. The correlation co-efficient value between percentage of fungi and physical purity of seeds was +0.340 (Table 2).
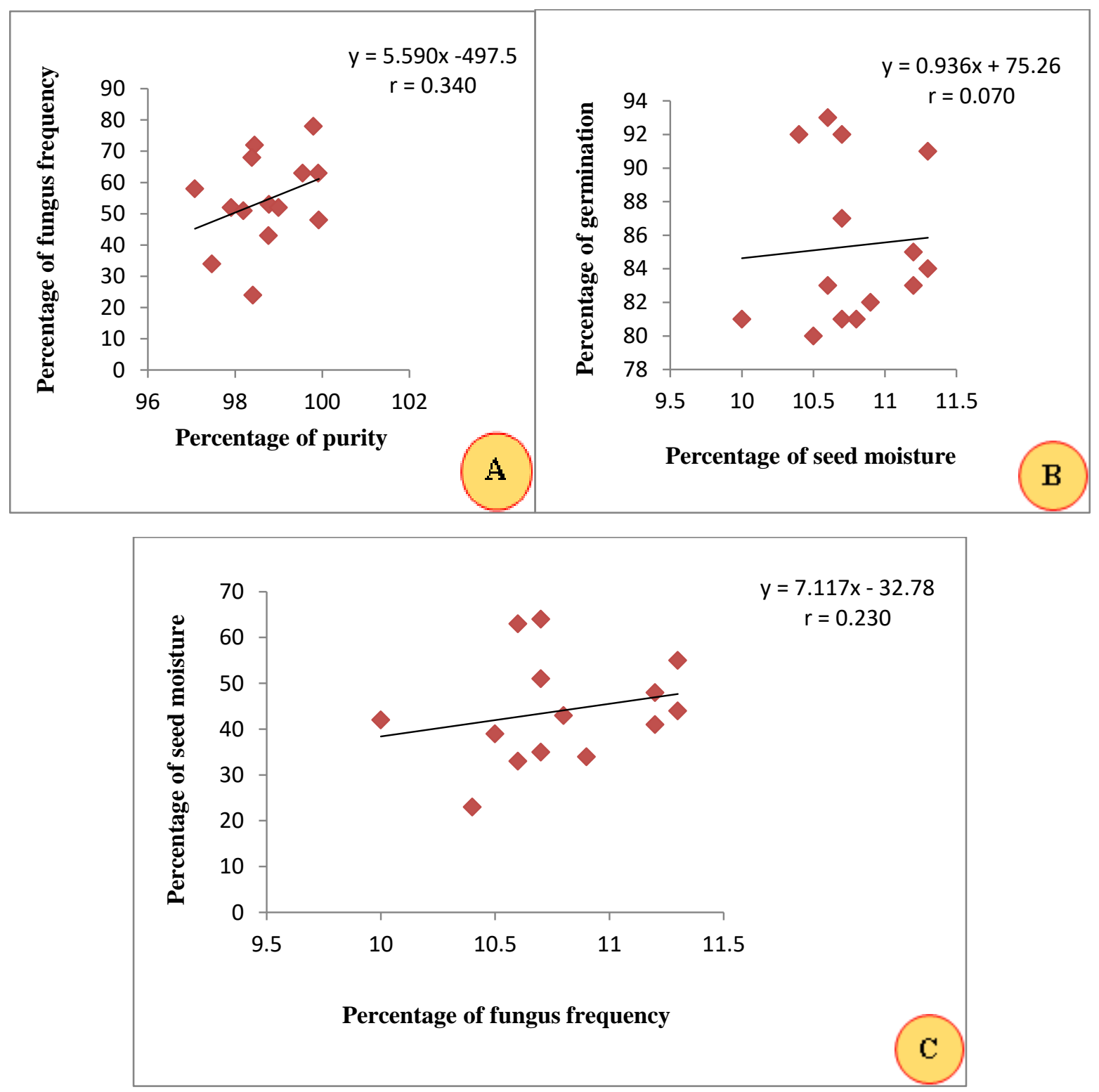

Figure 3.Correlation co-efficient and regression equation between A. percentage of frequency and percentage of purity B. percentage of germination and percentage of seed moisture C. percentage of seed moisture and percentage of fungus frequency.

The relationship between germination and seed moisture percentage shows positive correlation between two variables (Fig. 3B). Here regression line gives upward slopping curve, which means that both the variable changes in the same direction. The correlation co-efficient value between germination rate and seed moisture was +0.070 (Table 2).

The relationship between seed moisture and percentage of fungus frequency shows positive correlation between two variables (Fig. 3C). The correlation co-efficient value between percentage of fungi and seed moisture was +0.230 (Table 2).

The average physical purity of cotton seeds was recorded $98.69 \%$ in the present investigation. The result agrees with the

Fig. 2B, 2C and 3A shows positive correlation which means that both the variable changes in the same direction. These annual report of CDB (Cotton Development Board).The average germination and moisture of seeds in this study was $85.36 \%$ and $10.78 \%$ respectively. The results also agree with the standard value of CDB recommendation.

The saprophytic fungi though non-pathogenic, have the ability to secrete toxic metabolites which damages the quality of seed in storage ${ }^{23}$. Among the saprophytes Aspergillus flavus, A. fumigatus, A. nigerand Curvularia lunata were found to affect germination $^{24}$.

Fig. 2D indicates that increase of one variable (i.e., germination or frequency of fungi) decrease of the other variable (i.e., germination or frequency of fungi). This result was dissimilar with the result of Khandakar ${ }^{25}$.

results are similar with the findings of Khatun and Shamsi ${ }^{20}$ and Mamun et $_{\mathrm{al}}{ }^{26}$ 
Table 1. Seed quality analysis in different varieties of cotton (CB1-14).

\begin{tabular}{|c|c|c|c|c|c|}
\hline $\begin{array}{l}\text { Name of } \\
\text { Varieties }\end{array}$ & $\begin{array}{c}\text { Seed purity } \\
(\%)\end{array}$ & $\begin{array}{c}\text { Seed } \\
\text { germination } \\
(\%)\end{array}$ & $\begin{array}{c}\text { Seedling } \\
\text { mortality } \\
(\%)\end{array}$ & $\begin{array}{c}\text { Associated } \\
\text { fungi } \\
(\%)\end{array}$ & $\begin{array}{c}\text { Seed } \\
\text { Moisture } \\
(\%)\end{array}$ \\
\hline CB 1 & $99.55^{\mathrm{abc}}$ & $82^{\text {efg }}$ & $25.39^{\mathrm{def}}$ & $63^{\mathrm{d}}$ & $10.9^{b}$ \\
\hline CB 2 & $98.78^{\mathrm{cde}}$ & $83^{\text {de }}$ & $27.71^{\text {cdef }}$ & $53^{\mathrm{f}}$ & $10.6^{\mathrm{cd}}$ \\
\hline CB 3 & $99.0^{\text {cde }}$ & $85^{\mathrm{cd}}$ & $35.29^{\mathrm{bc}}$ & $52^{f}$ & $11.2^{\mathrm{a}}$ \\
\hline CB 4 & $98.45^{\text {abcde }}$ & $80^{\mathrm{g}}$ & $31.25^{\mathrm{cde}}$ & $72^{b}$ & $10.5^{\mathrm{d}}$ \\
\hline CB 5 & $99.91^{\mathrm{ab}}$ & $81^{\mathrm{fg}}$ & $33.33^{\mathrm{cd}}$ & $63^{\mathrm{d}}$ & $10.0^{\mathrm{e}}$ \\
\hline CB 6 & $97.47^{\mathrm{de}}$ & $87^{\mathrm{c}}$ & $43.93^{\mathrm{ab}}$ & $34^{\mathrm{i}}$ & $10.7^{\mathrm{bc}}$ \\
\hline CB 7 & $98.77^{\mathrm{abcd}}$ & $81^{\mathrm{fg}}$ & $16.05^{\mathrm{g}}$ & $43^{\mathrm{h}}$ & $10.7^{\mathrm{bc}}$ \\
\hline CB 8 & $98.41^{\text {abcde }}$ & $92^{\mathrm{ab}}$ & $23.91^{\mathrm{efg}}$ & $24^{\mathrm{j}}$ & $10.4^{\mathrm{d}}$ \\
\hline CB 9 & $98.39^{\text {abcde }}$ & $81^{\mathrm{fg}}$ & $45.89^{a}$ & $68^{c}$ & $10.8^{\mathrm{bc}}$ \\
\hline CB10 & $99.80^{\mathrm{abc}}$ & $93^{\mathrm{a}}$ & $26.88^{\mathrm{fg}}$ & $78^{\mathrm{a}}$ & $10.6^{\mathrm{bcd}}$ \\
\hline CB11 & $97.91^{\mathrm{cde}}$ & $92^{\mathrm{ab}}$ & $50.30^{\mathrm{a}}$ & $52^{f}$ & $10.7^{b}$ \\
\hline CB12 & $97.08^{\mathrm{e}}$ & $84^{\mathrm{ef}}$ & $21.43^{\mathrm{fg}}$ & $58^{\mathrm{e}}$ & $11.3^{\mathrm{a}}$ \\
\hline CB13 & $99.92^{\mathrm{a}}$ & $83^{\text {ef }}$ & $22.98^{\text {efg }}$ & $48^{g}$ & $11.2^{\mathrm{a}}$ \\
\hline CB14 & $98.19^{\text {bcde }}$ & $91^{b}$ & $47.88^{\mathrm{a}}$ & $51^{\mathrm{f}}$ & $11.2^{\mathrm{a}}$ \\
\hline CV (\%) & 0.5320 & 1.17 & 9.70 & 1.84 & 0.9297 \\
\hline
\end{tabular}

Means followed by the same letter within a column did not differ significantly at 5\% level of probability by DMRT.

Table 2. Correlation co-efficient (r) between some quality factors of cotton seeds.

\begin{tabular}{|lc}
\hline \multicolumn{1}{c}{ Quality factors } & Correlation co-efficient (r) \\
\hline Seedling mortality (\%) and physical purity $(\%)$ & -0.584 \\
\hline Seedling mortality (\%) and fungus frequency $(\%)$ & +0.055 \\
\hline Germination rate $(\%)$ and physical purity $(\%)$ & +0.394 \\
\hline Germination rate $(\%)$ and fungus frequency $(\%)$ & -0.273 \\
\hline Fungus frequency $(\%)$ and physical purity $(\%)$ & +0.340 \\
\hline Germination rate $(\%)$ and seed moisture $(\%)$ & +0.070 \\
\hline Seed moisture $(\%)$ and fungus frequency $(\%)$ & +0.230 \\
\hline
\end{tabular}

Fig. $2 \mathrm{~A}$ and $2 \mathrm{C}$ shows negative correlation which indicates that increase of one variable decrease of another variable. This result was also similar with the result of Khatun and Shamsi ${ }^{20}$ and Mamun et $a l .{ }^{26}$.
Fig. 3B shows positive correlation which means that both the variable changes in the same direction. This result was dissimilar with the result of Droworth and Christensen ${ }^{27}$.

Figure $3 \mathrm{C}$ shows positive correlation which means that both the variable change in the same direction. That means if the 
moisture content of seeds become high the fungus frequency also become high. This result was similar with the result of Delhom and Rodgers ${ }^{28}$, Droworth and Christensen ${ }^{27}$ and Harman et al. $^{29}$.

\section{Conclusions}

The present investigation revealed that, the cotton variety with the lowest fungal incidence showed the highest seed germination and again the cotton variety with the lowest fungal incidence showed the lowest mortality of seedlings. CB8 was superior from the other cotton variety as it showed higher physical purity of seed $(98.41 \%)$, higher seed germination $(92 \%)$, lower fungal incidence $(24 \%)$ and lower mortality of seedling (23.91\%) (Table 1). Moreover, CB12, CB13 and CB14 also showed comparatively better purity level, higher germination, lower fungal incidence and lower mortality rate. Therefore, these four varieties can be recommended by Bangladesh Cotton Development Board as suitable cotton variety for cultivation to the farmer's level.

\section{Acknowledgement}

The first author gratefully acknowledges to the "Ministry of Science and Technology", People's Republic of Bangladesh for providing financial support in her research through NST fellowship.

\section{References}

1. Munro JM, 1994. Cotton and its production, insect pests of cotton, CAB Intl., pp. 47-52.

2. Mathews GA, 1989. Cotton insect, pest and their management, Longman Scientific and Technical Longman group UK Limited, Longman House, Burnt Mill, Harlow, Assex, England, pp. 153-157.

3. Anonymous, 2017. The Annual Report and Work plan 2016-2017, Cotton Development Board (CDB), Khamarbari, Farmgate, Dhaka- 1215.

4. Machado JC, 2002. Concept and grouping fungi in relation to seed health testing - an overview. In: Seedborne fungi: a contribution to routine seed health analysis. Zurich: International Seed Testing Association, pp. 9-18.

5. BARI, 1990. Survey and monitoring of cotton diseases. Plant Pathology Research. Annual Report for 1989-90, pp. 67-69.

6. Lutfunnessa, R.J.F. and S. Shamsi. 2011. Fungal diseases of cotton plant (Gossypium hirsutum L.) in Bangladesh. Dhaka Univ. J. Biol. Sci. 20(2): 139-146.

7. CAB (Commonwealth Agricultural Bureau), 1968. Plant Pathologist Pocket Book. 1st edn. The Commonwealth Mycological Institute, England. 267 pp.

8. ISTA, 1996. International Rules of Seed Testing Association. In. Proc. Int. Seed Test. Assoc. pp 19-41.

9. Thom C. and Raper KB, 1945. A Manual of the Aspergilli. Williams and Wilkins, Baltimore, M.D. USA, pp. ix +373 .

10. Raper KB and Thom C, 1949. Manual of the Penicillia, Williams and Wilkins, Baltimore, MD. USA, pp. ix + 875.

11. Subramanian CV, 1971. Hyphomycetes. Indian Council of Agriculture Research, New Delhi, pp. 930.
12. Barnett HL and Hunter SB, 1972. Illustrated Genera of Imperfect Fungi. Burgess Publishing Company, USA Third Edition, pp. 44-45.

13. Benoit MA and Mathur SB, 1970. Identification of species Curvularia on rice seed. Proc. Inst.Seed Test. Ass., 35(1): 1-23.

14. Booth C, 1971. The Genus Fusarium. The Commonwealth Mycological Institute, Kew,England. $267 \mathrm{pp}$.

15. Ellis MB, 1971. Dematiaceous Hyphomycetes. $1^{\text {st }}$ edn. The Commonwealth Mycological Institute, Kew, Surrey, England. 608 pp.

16. Ellis MB, 1976. More Dematiaceous Hyphomycetes. The Commonwealth Mycological Institute, England. 507 pp.

17. Sutton BC, 1980. The Coelomycetes, Commonwealth Mycological Institute, Kew Surrey, England, 696 pp.

18. Amer et al., 2011. Non liquid nitrogen-based-method for isolation of DNA from filamentous fungi. African Journal of Biotechnology.10(65):14337-1434.

19. Spur HWJ and Wetly RE, 1972. Incidence of tobacco leaf micro flora in relation to brown spot disease and fungicidal treatment. Phytopathol. 62: 916-920.

20. Khatun A and Shamsi S, 2016. Estimation of interrelationship among seed germination, purity, seedling mortality and association of fungi with seeds of chickpea. Bangladesh J. Bot.45(3): 693-698.

21. Shamsi S and Khatun A, 2016. Prevalence of fungi in different varieties of chickpea (Cicer arietinum L.) seeds in storage. J. Bangladesh Acad. Sci., 40(1): 37-44.

22. Steel RGD and Torrie JH, 1960. Principles and Procedures of Statistics. McGraw-Hill Book Co., New York, pp. xvi + 481 .

23. Christensen CM, 1972. Microflora and seed deterioration in viability of seeds (ed. Roberts EH) Chapman and Hall, London.

24. Fazli SF and Ahmed QA, 1959. Effect of associated fungi on seeds and their effect on germinating seeds and seedling. Agriculture Pakistan.11(3): 393-406.

25. Khandakar AL, 1987. A pilot survey on the production and quality of jute seed at farm level. Bangladesh Agricultural Research Council, pp. 1-64.

26. Mamun MD, Shamsi S and Bashar MA, 2016. Estimation of interrelationships among some quality factors of jute seeds. Dhaka Univ. J. Biol. Sci.25(1): 917.

27. Droworth CP and Christensen CM, 1968. Influence of moisture content, temperature and storage time upon changes in fungus flora, germination ability and fat acidity, values of Soybeans. Phytopathol. 58: 1457-1959.

28. Delhom C and Rodgers J, 2016. Cotton moisture-its importance, measurements and impacts. United States Department of Agriculture, Agricultural Research Service New Orleans, LA, USA. $33^{\text {rd }}$ International Cotton Conference Bremen, pp. 1-7.

29. Harman GE, Granett AL and Narth G, 1972. Seed deterioration of storage fungi. New York. Food Life Science Quarterly. 5(2): 19-22. 